\title{
AKTUALISASI NILAIANEKA PADA PROFESI DOSEN IHDN DENPASAR SEBAGAI DASAR KOMITMEN MUTU PELAYANAN PUBLIK
}

\author{
Oleh \\ Putu Santi Oktarina \\ Dosen pada Fakultas Dharma Acarya IHDN Denpasar
}

\begin{abstract}
Apparatus profession as a lecturer in the Civil State plays an important role in improving the quality of the institution's commitment. Hindu Dharma Institute Denpasar State that has a vision leader in Dharma, Widya and Cultural expects all institutions including structural staff and functional staff, the lecturers, able to actualize the value of accountability, nationalism, public ethics, commitment to quality, and anti-corruption in the implementation of their obligations. However, a very small number of lecturers who have demonstrated commitment in improving public services especially for students. Therefore, through this paper, some activities were designed in internalizing the values of ANEKA.
\end{abstract}

Key words: actualization, commitment to quality, community service, ANEKA

\section{PENDAHULUAN}

Pegawai Negeri Sipil (ASN) merupakan Aparatur Sipil Negara (ASN) yang memiliki peranan penting dalam mengelola kondisi Indonesia saat ini. Sejumlah kebijakan, keputusan-keputusan strategis, perencanaan pembangunan, dan pelayanan terhadap masyarakat ditetapkan dan dilakukan oleh ASN di berbagai sektor pembangunan. Untuk memainkan peranan tersebut, diperlukan sosok ASN yang profesional, yaitu ASN yang mampu memenuhi standar kompetensi dan melaksanakan tugas jabatannya secara efektif dan efisien.

Keberhasilan penyelenggaraan suatu pemerintahan dan pembangunan sangat ditentukan oleh komitmen mutu serta profesionalisme aparatur negaranya. Sesuai dengan UU No 5 Tahun 2014 Tentang ASN, bahwa menjadi ASN harus memiliki sikap profesional yang tercemin dari pengaktualisasian nilai-nilai Akuntabilitas, Nasionalisme, Etika
Publik, Komitmen Mutu, dan Anti Korupsi yang tidak hanya dipahami sebagai sekadar nilai namun juga harus mengaktualisasikannya pada setiap perkataan, tindakan dan perilaku ketika melaksanakan tugas dan fungsinya di unit kerja masing-masing. Hal tersebut juga berlaku di lembaga Institut Hindu Dharma Ngeri Denpasar (disingkat IHDN Denpasar). Setiap anggota lembaga yang meliputi tenaga struktural maupun tenaga fungsional diharapkan mampu memegang teguh nilai-nilai ANEKA dalam menjalankan kewajiban. Terkait dengan tugas penulis sebagai dosen maka tugas jabatan fungsionalnya adalah melaksanakan Tri Dharma Perguruan Tinggi. Sesuai Peraturan Pemerintah Republik Indonesia No. 37 Tahun 2009, dosen dikatakan sebagai pendidik profesional dan ilmuwan dengan tugas utamanya untuk mentransformasikan, mengembangkan, dan menyebarluaskan ilmu pengetahuan, teknologi, dan seni melalui pendidikan, penelitian, dan pengabdian kepada masyarakat. Melihat 
betapa pentingnya tugas dosen, diharapkan dosen dapat mengaktualisasikan kelima nilai dasar (akuntabilitas, nasionalisme, etika publik, komitmen mutu, dan anti korupsi) secara profesional dalam menjalankan tugas dan fungsinya sebagai dosen.

Terkait dengan kualitas pelayanan publik, khususnya dosen, sangatlah penting bagi mereka untuk menunjukkan komitmennya dalam meningkatkan mutu kinerja. Aktualisasi nilai-nilai dasar profesi ASN yang tergabung dalam ANEKA (Akuntabilitas, Nasionalisme, Etika Publik, Komitmen Mutu dan Anti Korupsi) ini bertujuan untuk menginternalisasikan nilai dasar tersebut dalam diri dosen untuk membentuk dosen yang jujur, adil, disiplin, berintergritas, professional, mengutamakan kepentingan Negara dan masyarakat, dapat memelihara persatuan bangsa, serta selalu setia dan taat kepada Negara Kesatuan dan Pemerintah Republik Indonesia. Dengan demikian, pada pembahasan selanjutnya akan dipaparkan nilai-nilai ANEKA yang diaktualisasikan dalam tugas pokok dan fungsi dosen khususnya di lingkungan IHDN Denpasar, serta untuk menganalisis dampak yang terjadi apabila nila-nilai tersebut tidak diindahkan.

\section{PEMBAHASAN}

\section{A. Aktualisasi Nilai ANEKA}

Pelayanan Publik adalah segala kegiatan yang dilaksanakan oleh penyelenggara pelayanan publik sebagai upaya pemenuhan kebutuhan penerima pelayanan, dalam pelaksanaan ketentuan peraturan perundangundangan. Standar pelayanan publik terdiri dari prosedur pelayanan, waktu penyelesaian, produk pelayanan, biaya pelayanan, sarana dan prasarana, serta kompetensi petugas pemberi pelayanan. Berkaitan dengan hal tersebut, dosen memiliki kewajiban untuk memberikan pelayanan publik yang berkualiatas kepada para stakeholder, mahasiswa, dan masyarakat.
Pelayanan publik dapat dimaksimalkan dengan nilai dasar yang harus diaktualiasasikan berdasarkan peraturan perundang-undangan. Sesuai dengan UU No. 5 Tahun 2014 Tentang ASN, bahwa menjadi Aparatur Sipil Negara (ASN) harus mampu mengaktualisasikan lima nilai dasar ASN yang terdiri dari Akuntabilitas, Nasionalisme, Etika Publik, Komitmen Mutu, dan Anti Korupsi. Lima nilai dasar yang biasa disingkat ANEKA ini merupakan modal awal ASN dalam menjalankan tugasnya. Dosen yang merupakan bagian ASN juga berkewajiban menjalankan nilai ANEKA. Sebelum mengimplementasikan nilai dasar ASN, ada satu tahap yang dilalui yaitu tahap internalisasi. Internalisasi merupakan proses pemahaman atas nilai yang terkandung dari masing-masing poin ANEKA. Tahapan selanjutnya yaitu aktualisasi nilai ANEKA yang berarti mengambil tindakan sesuai dengan nilai-nilai ANEKA. ANEKA merupakan singkatan dari akuntabilitas, nasionalisme, etika publik, komitmen mutu, anti-korupsi.

Nilai pertama adalah akuntabilitas. Akuntabilitas merupakan kesadaran adanya tanggung jawab dan kemauan untuk bertanggung jawab. Dosen memiliki tugas pokok fungsi yang wajib untuk dijalankan. Setiap dosen hendaknya sadar akan tugasnya. Mereka juga harus bertanggung jawab atas apa yang telah dilaksanakan. Dalam hal ini, sangatlah penting bagi dosen untuk melakukan perencanaan yang matang sebelum melaksanakan tugasnya. Adanya transparansi juga penting untuk dilaksanakan. Tanpa transparansi dosen akan kesulitan dalam menjalankan tugas. Dalam tupoksi (tugas pokok dan fungsi) dosen, akuntabilitas ini telah dilaksanakan dengan cukup baik terlihat dari dibuatnya laporan setelah kegiatan workshop, stadium general, seminar, dan lain-lain. Kegiatan tersebut sudah mencerminkan aktualisasi nilai akuntabilitas dalam tugas dosen. Akan tetapi, akutabilitas akan bermakna maksimal apabila penyelesaian laporan dilaksanakan tepat waktu. 
Apabila terjadi keterlambatan, nilai akuntabilitas secara otomatis akan menurun sehingga mutu pelayanan publik tidak terpenuhi dengan baik.

Nilai kedua adalah nasionalisme. Nasionalisme merupakan sikap menjunjung tinggi nilai-nilai Pancasila. Setiap sila dalam Pancasila mengandung nilai-nilai kemuliaan. Sila pertama, Ketuhanan yang Maha Esa. Kedua, Kemanusiaan yang adil dan beradab. Ketiga, Persatuan Indonesia. Keempat, Kerakyatan yang dipimpin oleh hikmat kebijaksanaan dalam permusyawaratan perwakilan. Kelima, Keadilan sosial bagi seluruh rakyat Indonesia. Lima sila ini merupakan pondasi dan pandangan hidup bangsa Indonesia. Sebagai motor penggerak suatu negara, dosen harus mampu menjadi teladan. Komunikasi yang baik antara dosen dengan dosen lainnya, dosen dengan pegawai, maupun dosen dengan mahasiswa merupakan pengejawantahan dari aktualisasi nilai-nilai Pancasila. Takwa kepada Tuhan Yang Maha Esa, menunjukkan sikap toleransi dan demokratis dalam setiap pertemuan atau rapat, serta melaksanakan pengabdian masyarakat yang didasarkan pada kebutuhan masyarakat, merupakan contoh kewajiban dosen yang mengaktualisasikan nilai nasionalisme.

Nilai ketiga adalah etika publik. Etika publik berkenaan erat dengan publik dalam hal berbagai stakeholder yang berhubungan dengan tupoksi dosen. Ricocur (1990) mendefinisikan etika sebagai tujuan hidup yang baik bersama dan untuk orang lain di dalam institusi yang adil. Selanjutnya etika publik merupakan refleksi atas standar/ norma yang menentukan baik/ buruk, benar/ salah tindakan keputusan, perilaku untuk mengarahkan kebijakan publik dalam rangka menjalankan tanggung jawab pelayanan publik. Nilai-nilai dasar etika publik sebagaimana tercantum dalam Undang-Undang ASN, yakni memegang teguh nilai-nilai dalam ideologi Negara Pancasila; Setia dan mempertahankan Undang-Undang Dasar Negara Kesatuan Republik Indonesia 1945; menjalankan tugas secara profesional dan tidak berpihak; membuat keputusan berdasarkan prinsip keahlian; menciptakan lingkungan kerja yang non diskriminatif; memelihara dan menjunjung tinggi standar etika luhur; mempertanggung jawabkan tindakan dan kinerjanya kepada public; memiliki kemampuan dalam melaksanakan kebijakan dan program pemerintah; memberikan layanan kepada publik secara jujur, tanggap, cepat, tepat, akurat, berdaya guna, berhasil guna, dan santun; mengutamakan kepemimpinan berkualitas tinggi; menghargai komunikasi, konsultasi, dan kerjasama; mendorong kesetaraan dalam pekerjaan; meningkatkan efektivitas sistem pemerintahan yang demokratis sebagai perangkat sistem karir.

Keempat, komitmen mutu merupakan sikap menjaga keefektifan, efisiensi, dan inovasi kerja demi mencapai mutu atau kualitas tertentu. Mutu dosen dalam menjalankan tugas hendaknya mengalami kemajuan dari waktu ke waktu. Ada tuntutan kreativitas bagi setiap individu dalam menjalankan tugas sehari-hari. Komitmen mutu berkaitan erat dengan managemen mutu seperti yang dikemukakan oleh Listyorini, dkk; 2015 bahwa managemen mutu menyeluruh (Total Quality Management/ TQM) merupakan suatu pendekatan dalam menjalankan usaha yang mencoba untuk memaksimumkan daya saing organisasi melalui perbaikan terus menerus atas produk, jasa, manusia, proses, dan lingkungannya. Salah satu contoh tugas dosen yang mencerminkan aktualisasi nilai komitmen mutu adalah penyusunan SAP dan Silabus secara berkala. Meskipun setiap tahunnnya mengajar mata kuliah yang sama, dosen diharapkan tetap mengembangkan perencanaan pembelajaran sesuai dengan kebutuhan serta kemampuan mahasiswa yang berbeda.

Kelima, anti korupsi merupakan sikap tegas memerangi korupsi. Memutus mata rantai korupsi dapat diawali dari diri sendiri. Baik itu korupsi waktu, korupsi uang, maupun korupsi tugas. Setiap individu hendaknya dapat menjadi pengingat bagi dirinya masing-masing. 
Contohnya berada di lokasi sebelum jam kerja dimulai, tidak meninggalkan tempat kerja tanpa alasan jelas sebelum jam kerja usai, dan tidak menggunakan uang negara untuk memenuhi kebutuhan pribadi. Sebagai ASN yang profesional dan memegang teguh prinsip anti korupsi, seorang ASN diharapkan dapat mengaktualisasikan nilai-nilai dasar anti korupsi dalam kehidupan sehari-harinya yang meliputi jujur, peduli, mandiri, disiplin, tanggung jawab, kerja keras, sederhana, berani, dan adil.

Kelima nilai di atas hendaknya dapat diaktualisasikan oleh para dosen sebagai dasar komitmen mutu pelayanan publik. Pelayanan bublik yang dimaksud merupakan pelayanan untuk mahasiswa maupun masyarakat secara luas. Hal tersebut telah tergambarkan dengan sangat jelas dalam Tri Dharma Perguruan Tinggi yang meliputi aspek pengajaran yang merupakan pengejawantahan pelayan publik dosen terhadap mahasiswa. aspek selanjutnya adalah penelitian yang merupakan upaya pelayanan publik untuk meningkatkan profesionalisme dosen serta memberikan kontribusi kepada masyarakat. Aspek yang terakhir yaitu pengabdian masyarakat yang berkontribusi langsung pada masyarakat.

\section{B. Analisis Dampak}

Dalam profesinyaa sebagai ASN, dosen bertanggung jawab untuik mengaktualisasikan nilai-nilai ANEKA dalam tugas pokok dan fungsinya.. Namun, apabila nilai-nilai ANEKA tersebut tidak diaktualisasikan, akan membawa dampak negatif terhadap kegiatan yang dilaksanaan. Akuntabilitas merujuk pada kewajiban setiap individu atau institusi untuk memenuhi tanggung jawab yang menjadi amanahnya. Sehingga akuntabilitas dapat diterapkan melalui sikap tangung jawab. Adapun tanggung jawab secara definisi merupakan kesadaran manusia akan tingkah laku atau perbuatan baik yang disengaja maupun yang tidak di sengaja. Tanggung jawab juga berarti berbuat sebagai perwujudan kesadaran akan kewajiban. Tanggung jawab bersifat kodrati, yang artinya tanggung jawab itu sudah menjadi bagian kehidupan manusia bahwa setiap manusia dan yang pasti masingmasing orang akan memikul suatu tanggung jawabnya sendiri-sendiri. Dalam aktualisasi nilai-nilai dasar ASN di IHDN Denpasar dapat dilihat dari adanya rasa tangung jawab dalam melaksanakan tugas sesuai tengan tupoksi. Jika rasa tangung jawab ini tidak dimiliki oleh dosen maka hasil yang diperoleh dalam setiap tugas yang dibebankan menjadi tidak maksimal, sehingga amanah sebagai pegawai negeri sipil yang akuntable tidak dapat dipenuhi.

Rasa nasionalisme juga sangat penting dimiliki oleh seorang dosen. Nasionalisme adalah suatu sikap politik dari masyarakat suatu bangsa yang mempunyai kesamaan kebudayaan, dan wilayah serta kesamaan citacita dan tujuan, dengan demikian masyarakat suatu bangsa tersebut merasakan adanya kesetiaan yang mendalam terhadap bangsa itu sendiri. Demikian juga ketika kita berbicara tentang nasionalisme. Nasionalisme merupakan jiwa bangsa Indonesia yang akan terus melekat selama bangsa Indonesia masih ada. Dengan memiliki rasa Nasionalisme maka seorang dosen akan berusaha bekerja dengan baik untuk memajukan negaranya. Jika seorang dosen tidak memiliki rasa nasionalisme maka yang terjadi adalah kepentingan pribadi akan lebih diutamakan daripada kepentingangan Negara. Dalam aktualisasi nilai-nilai dasar ASN di IHDN Denpasar dapat dilihat dari adanya rasa nasionalisme ditunjukkan dengan pengamalan dari setiap sila dalam Pancasila. Jika hal ini tidak terjadi maka akan terjadi perpecahan dalam lembaga IHDN Denpasar, yang nantinya akan berdampak negatif pada kinerja pegawai dan dosen.

Etika publik adalah refleksi tentang standar atau norma yang menentukan baik-buruk dan benar-salah suatu perilaku, tindakan, dan keputusan yang mengarahkan kebijakan publik dalam menjalankan tanggung jawab pelayanan 
publik. Ada tiga fokus etika publik. Pertama, pelayanan publik berkualitas dan relevan. Artinya, kebijakan publik harus responsif dan mengutamakan kepentingan publik. Kedua, fokus refleksi karena tak hanya menyusun kode etik atau norma, etika publik membantu mempertimbangkan pilihan sarana kebijakan publik dan alat evaluasi yang memperhitungkan konsekuensi etis. ketiga fungsi ini menciptakan budaya etika dalam organisasi dan membantu integritas pejabat publik. Dalam aktualisasi nilainilai dasar ASN di IHDN Denpasar dapat dilihat dari adanya rasa etika publik adalah dengan memberi pelayanan yang ramah dan baik kepada masyarakat umumnya dan mahasiswa pada khususnya. Jika etika publik ini tidak diterapkan maka masyarakat pada umumnya dan mahasiswa pada khususnya akan merasa kecewa dan tidak percaya kepada pegawai dan dosen di IHDN Denpasar.

Indikator komitmen mutu dalam pelaksaan tugas dosen dicirikan pada pekerjaan yang berasaskan efiseinsi, efektivitas dan selalu berinovasi demi menjawab tantangan yang senantiasa berubah. Dalam aktualisasi nilai-nilai dasar ASN di IHDN Denpasar dapat dilihat dari adanya usaha untuk melakukan perubahan atau inovasi ke arah positif untuk kemajuan lembaga. Dengan adanya usaha tersebut maka secara perlahan akan mampu meningkatkan kualitas lembaga baik dari sisi pelayanan, lingkungan kerja dan hasil kinerja. Jika komitmen mutu tidak diterapkan maka yang terjadi adalah suasana kerja yang monoton dan membosankan. Dari suasana kerja seperti ini maka hasil kerjapun tidak maksimal dan masyarakat atau mahasiswa menjadi tidak mendapatkan pelayanan yang maksimal.

Nilai-nilai dasar anti korupsi harus dimiliki oleh setiap dosen. Semangat anti korupsi bertujuan untuk membangun niat, semangat dan komitmen melakukan pemberantasan korupsi. Tidak mencuri atau korupsi berarti non ketamakan: itu berarti tidak menginginkan halhal yang merupakan milik orang klain. Dalam aktualisasi nilai-nilai dasar ASN di IHDN Denpasar dapat dilihat dari datang tepat waktu, bersikap jujur dan adil dalam memberikan penilaian dan pengajaran serta tidak menerima gratifikasi dalam bentuk apapun. Apabila nilai dasar anti korupsi ini tidak dimiliki oleh dosen maka bisa menyebabkan kerugian Negara dan hilangnya kepercayaan masyarakat terhadap lembaga pemerintahan.

\section{SIMPULAN}

Dosen diharapkan mampu berkomitmen bekerja secara professional sehingga menghasilkan pelayanan publik yang berkualitas. Dosen perlu menanamkan nilai-nilai dasar profesi agar terwujudnya pendidikan berkualitas, sehingga dengan demikian keberadaan dosen yang berkompetensi merupakan syarat mutlak hadirnya sistim dan praktik pendidikan yang berkualitas. Dalam setiap kegiatan yang direncanankan, diharakan kelima unsur ANEKA diaktualisasikan dengan baik. Setiap tahapan kegiatan selama proses untuk mencapai tujuan hendaknya menyiratkan nilai-nilai ANEKA tersebut. Dengan demikian dapat dipastikan bahwa dosen akan menunjukkan pelayanan pubik yang maksimal sehingga berbagai stakeholder akan memperoleh manfaat atas segala kegiatan yang dilaksanakan dosen.

\section{DAFTAR PUSTAKA}

Lembaga Administrasi Negara. 2014. Aktualisasi Nilai-Nilai Dasar Profesi Pegawai Negeri Sipil. Modul Penyelenggaraan Perdana Pendidikan Dan Pelatihan Calon Pegawai Negeri Sipil Prajabatan Golongan II. Jakarta: Lembaga Administrasi Negara.

Listyorini, L., Hari D.U., dan Bambang A.N. 2012. Analisis Total Quality Management Dan Kinerja Finansial Koperasi Susu (Studi Kasus Di Kud "Tani Wilis" Tulungagung). Malang: Universitas 
Brahwijaya. Diakses pada 24 Oktober 2015: http://fapet.ub.ac.id/wp-content/ uploads/2013/04/Analisis-Total-QualityManagement-Dan-Kinerja-FinansialKoperasi-Susu-Studi-Kasus-di-KUD$\%$ E2\%80\%9CTani-Wilis\%E2\%80\%9DTulungagung.pdf

Peraturan Pemerintah Republik Indonesia Nomor 37 Tahun 2009 tentang Dosen

Peraturan Kepala Lembaga Administrasi Negara Nomor: 38 Tahun 2014 tentang Pedoman Penyelenggaraan Pendidikan dan Pelatihan Prajabatan Calon Pegawai Negeri Sipil Golongan III

Tim Penyusun. 2014. Akuntabilitas. Modul Penyelenggaraan Perdana Pendidikan Dan Pelatihan Calon Pegawai Negeri Sipil Prajabatan Golongan III. Jakarta: Lembaga Administrasi Negara.

Tim Penyusun. 2014. Anti Korupsi. Modul Penyelenggaraan Perdana Pendidikan Dan
Pelatihan Calon Pegawai Negeri Sipil Prajabatan Golongan III. Jakarta: Lembaga Administrasi Negara.

Tim Penyusun. 2014. Etika Publik. Modul Penyelenggaraan Perdana Pendidikan Dan Pelatihan Calon Pegawai Negeri Sipil Prajabatan Golongan III. Jakarta: Lembaga Administrasi Negara.

Tim Penyusun. 2014. Komitmen Mutu. Modul Penyelenggaraan Perdana Pendidikan Dan Pelatihan Calon Pegawai Negeri Sipil Prajabatan Golongan III. Jakarta: Lembaga Administrasi Negara.

Tim Penyusun. 2014. Nasionalisme. Modul Penyelenggaraan Perdana Pendidikan Dan Pelatihan Calon Pegawai Negeri Sipil Prajabatan Golongan III. Jakarta: Lembaga Administrasi Negara.

Undang Undang No 5 Tahun 2014 tentang Aparatur Sipil Negara. 